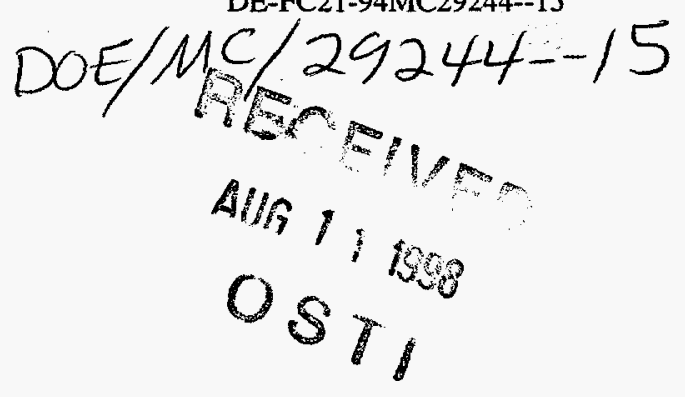

\title{
Disposal of Fluidized Bed Combustion Ash in an Underground Mine to Control Acid Mine Drainage and Subsidence
}

\author{
Quarterly Report \\ September 1 - November 30, 1997
}

Work Performed Under Contract No.: DE-FC21-94MC29244

By

West Virginia University Research Corp.

West Virginia University

P. O. Box 6101

Morgantown, West Virginia 26506-6103

U.S. Department of Energy

Office of Fossil Energy

Federal Energy Technology Center

P.O. Box 880

Morgantown, West Virginia 26507-0880
Morgantown, West Virginia $26506-6103$ 


\section{Disclaimer}

This report was prepared as an account of work sponsored by an agency of the United States Government. Neither the United States Government nor any agency thereof, nor any of their employees, makes any warranty, express or implied, or assumes any legal liability or responsibility for the accuracy, completeness, or usefulness of any information, apparatus, product, or process disclosed, or represents that its use would not infringe privately owed rights. Reference herein to any specific commercial product, process, or service by trade name, trademark, manufacturer, or otherwise does not necessarily constitute or imply its endorsement, recommendation, or favoring by the United States Government or any agency thereof. The views and opinions of authors expressed herein do not necessarily state or reflect those of the United States Government or any agency thereof. 


\section{DISCLAIMER}

Portions of this document may be illegible electronic image products. Images are produced from the best available original document. 
Progress Report

for the Period of

\title{
September 1, 1997 to November 30, 1997
}

Phase III, Quarter IIII

\begin{abstract}
Project - ETD05 "Disposal of Fluidized Bed Combustion Ash in an Underground Mine to Control Acid Mine Drainage and Subsidence"

DE-FC21-94MC29244 - -15
\end{abstract}

\section{EXECUTIVE SUMMARY}

This project will evaluate the technical, economic and environmental feasibility of filling abandoned underground mine voids with alkaline, advanced coal combustion wastes (Fluidized Bed Combustion -FBC ash). Success will be measured in terms of technical feasibility of the approach (i.e. \% void filling), cost, environmental benefits (acid mine drainage and subsidence control) and environmental impacts (noxious ion release).

Phase I of the project was completed in September 1995 and was concerned with the development of the grout and a series of predictive models. These models were verified through the Phase II field phase and will be further verified in the large scale field demonstration of Phase III. The verification will allow the results to be packaged in such a way that the technology can be easily adapted to different site conditions. Phase II was successfully completed with 1000 cubic yards of grout being injected into Anker Energy's Fairfax mine. The grout flowed over 600 feet from a single injection borehole. The grout achieved a compressive strength of over $1000 \mathrm{psi}$ (twice the level that is needed to guarantee subsidence control). Phase III is to take 26 months and will be a full scale test at Anker's eleven acre Longridge mine site.

It is expected that the FBC ash will replace what is now an acid mine pool with alkaline solid so that the groundwater will tend to flow around and through the pillare rather than through the previously mined areas. The project has demonstrated that $\mathrm{BC}$ ash can be successfully disposed in underground mines. Additionally, the project is directed towards showing that such disposal can lead to reduction or elimination of: environmental problems associated with underground mining such as acid mine drainage and subsidence.

During Phase III the majority of the activity involves completing two full scale demonstration projects. The eleven acre Longridge mine in Preston County will be filled with 53,000 cubic yards of grout during the spring of 1998 and monitored for following year. The second demonstration involves stowing 2000 tons of ash into an abandoned mine to demonstrate the newly redesigned Burnett Ejector. This 
demonstration is anticipated to take place during the winter of 1997.

This document will report on progress made during Phase III. The report will be divided into four major sections. The first will the Hydraulic Injection component. This section of the report will report on progress and milestones associated with the grouting activities of the project. The Phase III tasks of Economic Analysis and Regulatory Analysis will be covered under this section. The second component is Pneumatic Injection. This section reports on progress made towards completing the demonstration project. The Water Quality component involves background monitoring of water quality and precipitation at the Phase III (Longridge) mine site. The last component involves evaluating the migration of contaminants through the grouted mine. A computer model has been developed in earlier phases and will model the flow of water in and around the grouted Longridge mine. The Gantt Chart on the following page details progress by task. 


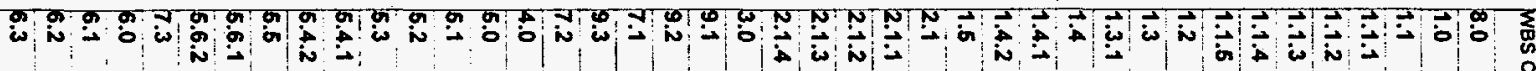

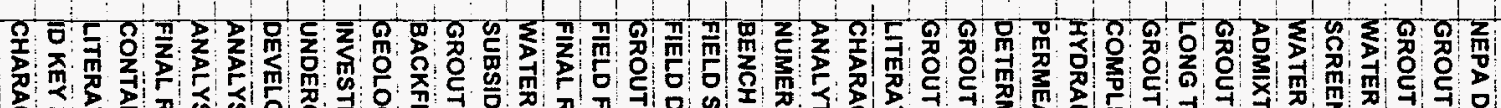

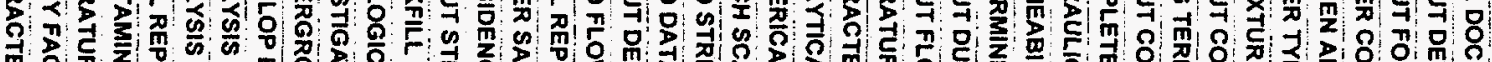

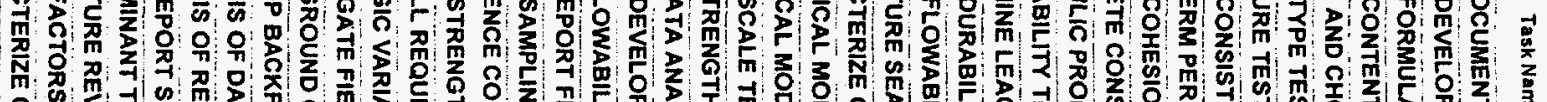

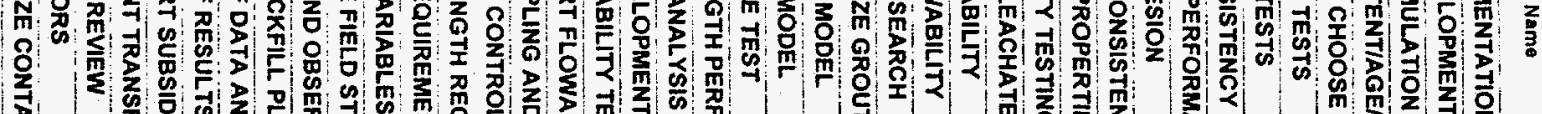

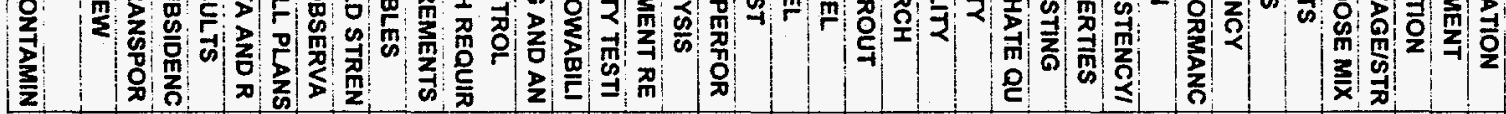

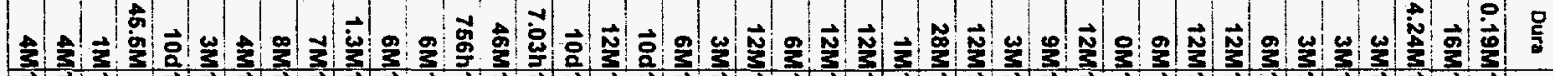
它

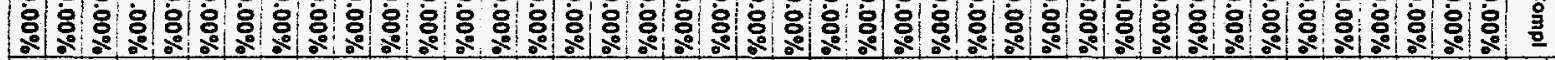
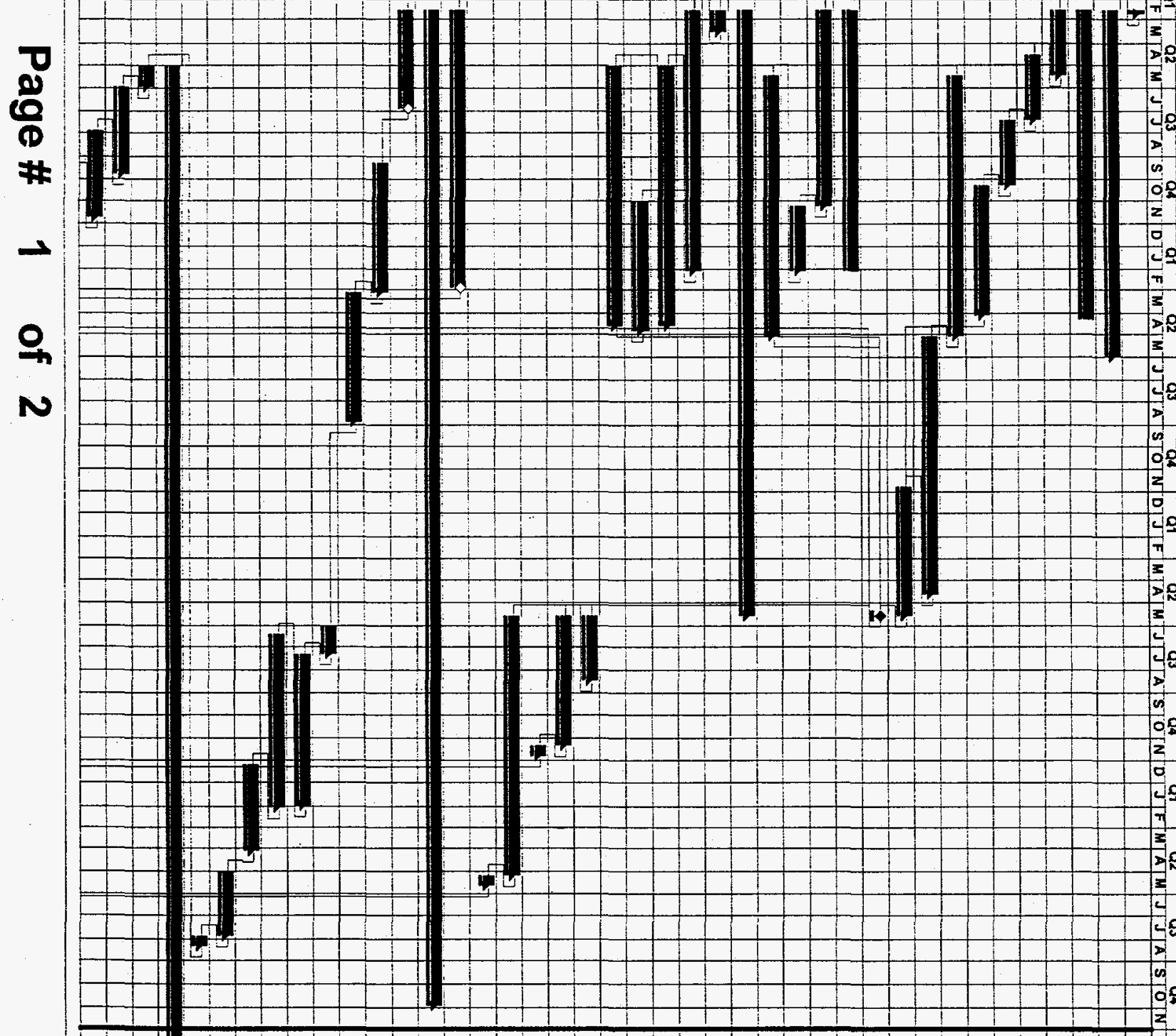

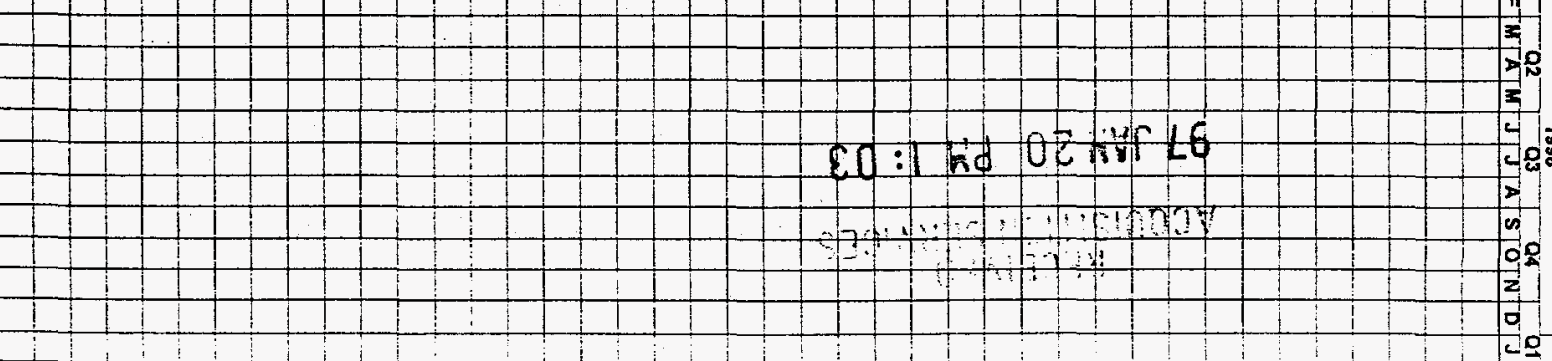




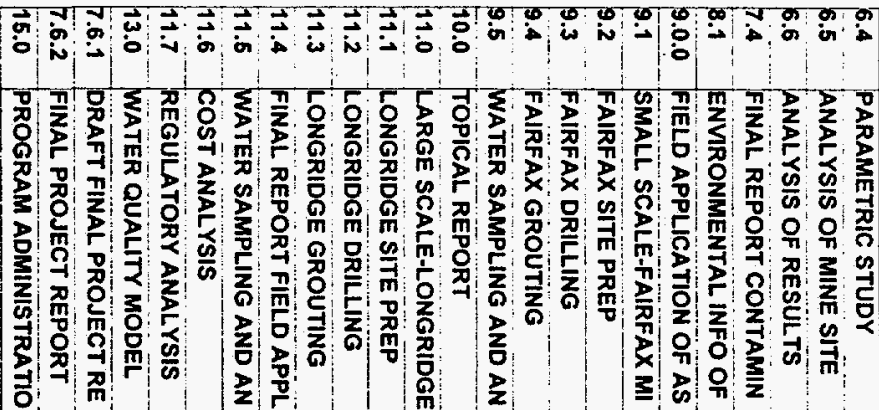

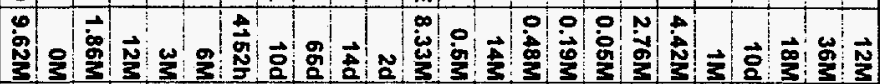

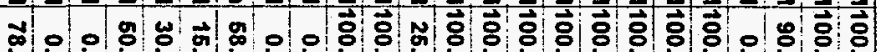
\%.

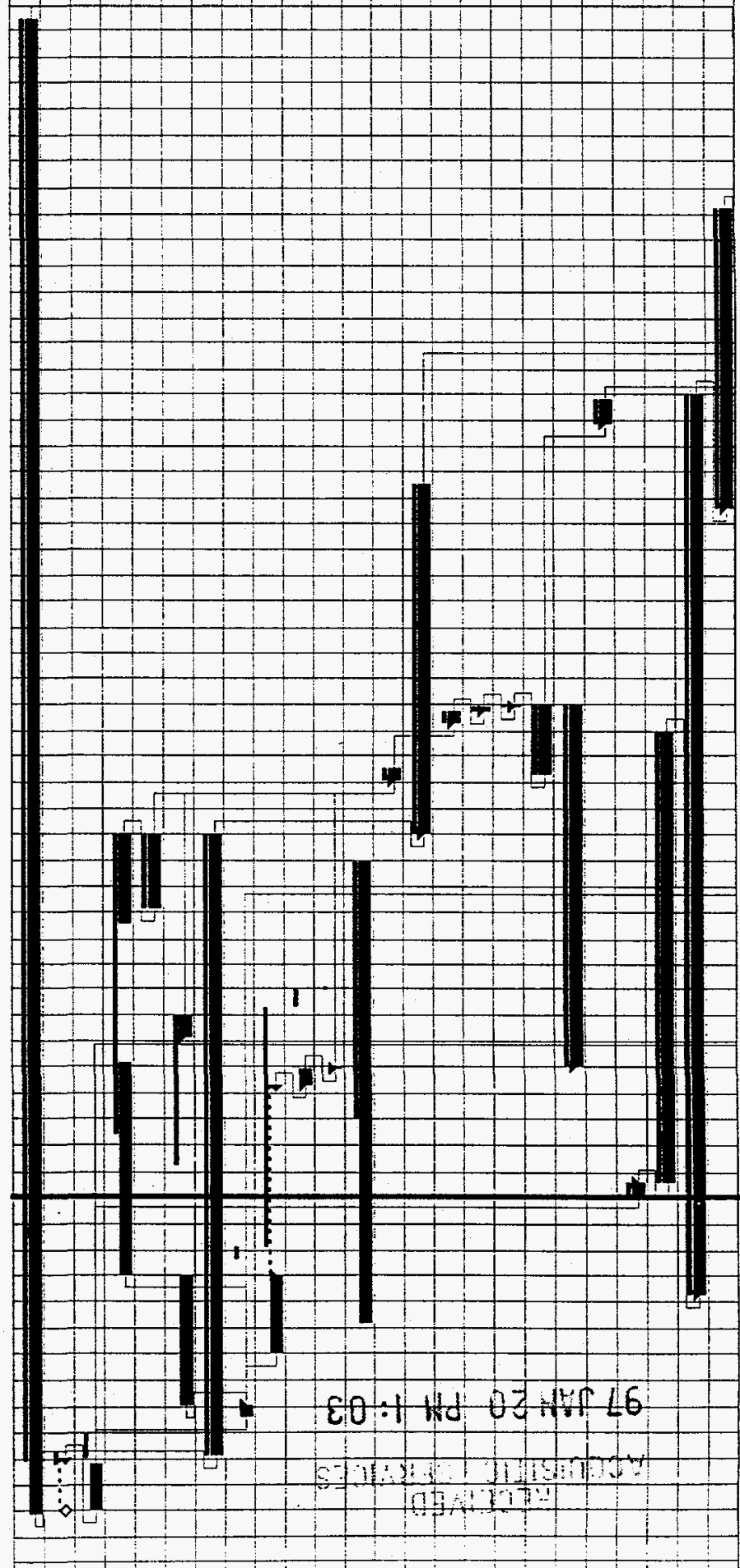


A. Hydraulic Injection

\subsection{Task Description:}

Task 11 - Hydraulic Injection: The purpose of this task is to grout the eleven acre Longridge mine with a grout consisting of coal combustion byproducts.

Task 12 - Economic Analysis: Burnett Engineering, Inc. shall develop economic analyses to compare the cost associated with disposal of coal ash in landfills with disposal of coal ash in underground mines to control subsidence and acid mine drainage.

Landfill disposal of MEA AFBC Power Plant ash. Burnett Engineering, Inc. shall develop an economic analysis for disposing of MEA AFBC ash in a landfill located near the Fairfax and Longridge mines. Costs to be included in the economic analysis include, but are not limited to, loading of ash at the power plant, transportation to the disposal site, landfill construction, landfill operation, landfill maintenance, and regulatory compliance. In addition, long-term cost impact on property values shall be estimated.

Landfill disposal practices of Northeast utilities. Burnett Engineering, Inc. shall use published data from the Electric Power Research Institute, and data from Monongahela Power Company and Allegheny Power Company to generate a range of cost estimates for disposing power plant ash in landfills. Burnett Engineering, Inc. shall describe the similarities and differences in ash disposal practices and costs for three utilities. Description of the similarities and differences shall include, but is not limited to, regulatory environment, environmental protection features in landfill design (e.g., liners), monitoring requirements, transportation, and ash handling.

Underground coal mine disposal of MEA AFBC Power Plant ash. Burnett Engineering, Inc. shall develop an economic analysis for disposing of MEA AFBC ash in the Longridge coal mine. Costs to be included in the economic analysis include, but are not limited to, loading of ash at the power plant, transportation to the disposal site, production of grout, injection of grout, mine maintenance, and regulatory compliance.

Burnett Engineering, Inc. shall analyze the costs associated with the benefits of underground mine disposal of the MEA AFBC Power Plant ash. These benefits include, but are not limited to, lower quantities of waste to be placed in the landfill, reduction in land subsidence, and improvements in water quality.

Task 13 - Water Quality Model: WVU shall use existing water quality model(s) or modifications of existing water quality model(s) to estimate the impact of ash disposal in underground mines on the concentrations of contaminants in nearby surface and ground water. Data from a geographical information system (GIS) 
shall be coupled with the water quality model results to estimate the impact of disposal of MEA AFBC ash in the Longridge mine on concentrations of contaminants in nearby surface and ground water.

Task 14 - Regulatory Analysis: WVU shall review existing Federal, State of West Virginia, and local regulations and policies which could impact the disposal of ash from advanced coal combustion technologies in underground mines. The contractor shall identify any regulatory barriers to the widespread adoption of this disposal practice in West Virginia.

\subsection{Summary of Accomplishments}

2.1 The proper value for the plastic viscosity of the AFBC ash grout has been established.

2.2 Successful simulations of the partial injection of the AFBC ash grout in an underground mine with a simple layout have been performed with Groutnet.

2.3 A postprocessing program for reading the Groutnet binary output data files and writing input files for Microsoft Excel and for Golden Software's Surfer has been developed.

2.4 The basic parameters and model layout for the simulation of the Longridge mine AFBC grout injection have been established.

2.5 A procedure for simulating the hardening of the injected AFBC grout between the proposed ten hour injections for the Longridge mine injection has been developed. This procedure involves reading the output from a Groutnet simulation of the previous day's injection and writing the input file for the Groutnet simulation of the next day's injection and is implemented with a preprocessing utility program.

2.6 Site preparation activities for the Longridge Mine were completed. Specifically, one mile of road was built to allow access to the site and the mine void was successfully drilled.

\subsection{To-Date Accomplishments}

Successfully completed Phase II grout injection. Completed site preparation activities for Phase III Demonstration.

\subsection{Technical Progress Report}

During this quarter the site preparation activities for the Longridge mine were completed. One mile of road was built using 3 " to 6 " sandstone as a base. The 
road will give the ash trucks access to the mixing area located above the mine void. The stock piling of cement kiln dust has begun and will continue until the 21,500 tons is located on site for the demonstration. Seventeen boreholes were drilled into the mine void. The U.S. Office of Surface Mining assisted in the drilling operations by providing a borehole camera to investigate the mine void. The camera proved extremely valuable as one heading contained a near perfect void while the other suffered from many roof falls. The video of the boreholes is being analyzed. A map of the mine and roof conditions will be presented in a topical report once the three hours of tape is analyzed.

As previously reported an alternative grout mix was being considered given the short-fall of FBC ash from the MEA Plant. An alternative mix containing a high LOI ash and cement kiln dust (CKD) has been accepted as a viable candidate for Phase III activities. The mix contains 30\% high LOI ash, 20\% CKD, and 50\% water by total weight of the mixture. The mix displays $<5 \%$ bleed, has consistent torque values from the rotational viscometer for 20 minutes and displays a spread of 11 inches. These values are consistent with the data reported for the Phase II grout mix. More data is being collected on the grout mixture to ensure that the Phase III demonstration will be as successful as the Phase II.

Preliminary estimates indicate that the grout can be placed underground for about $\$ 12.00$ per cubic yard. A full economic analysis will be completed once the demonstration project is underway.

A detailed topical report on the numeric modeling of the grout injection will be presented as soon as it is ready for release.

\subsection{Plans for Next Quarter}

5.1 Coordinate Phase III injection with coal company personnel.

5.2 Continue with numeric modeling of grouting operations.

5.2.1 The correction of the fatal numerical instability that Groutnet suffers as the injected grout begins to completely fill the mine.

5.2.2 A parametric study investigating the effects of the material, geometric, and finite difference Groutnet parameters on the injection of grout into a simple test mine.

5.2.3 The writing of a user's manual for Groutnet and the associated preprocessing and postprocessing computer programs.

5.2.4 A simulation of the test injection of the Fairfax mine.

5.2.5 An initial simulation of the injection of the Longridge mine. 


\section{B. Pneumatic Injection}

\subsection{Task Description}

The purpose of this task is to inject coal combustion byproducts into an underground mine via the Burnett Ejector. A complete economic analysis will be completed on the feasibility of this method of injection. Two thousand tons of ash are scheduled to be injected.

\subsection{Summary of Accomplishments \& Significant Events}

The fabrication of the camera and lighting mounts were completed.

\subsection{To Date Accomplishments}

Redesigned and manufactured pneumatic ejector.

\subsection{Technical Progress Report}

The stainless steel camera mount was modified to hold a 100 watt 12 Volt DC General Motors style headlight lamp. The camera and mounting system can be seen in Figure 1. The light and camera will be tested during January at the National Research Center for Coal and Energy at West Virginia University. The camera will be tested with a handheld video monitor that will be borrowed from the NRCCE during the Phase III field demonstration.

Other work during this quarter included the preliminary design of the wench system that will raise and lower the ejector and pipe into the mine void. A new plastic pipe is being investigated for use in the Phase III demonstration. The plastic pipe will be significantly lighter than the steel used previously. The objective is to make the pneumatic injection a "two man" operation. Since the price of compressed air and ash with transportation is generally fixed, savings are being sought on labor costs required to operate the system.

The full scale demonstration of the system was delayed due to inclimate weather at the site. The demonstration is being rescheduled for the Spring of 1998. The 2000 ton demonstration will take one week to complete.

\subsection{Plans for next Quarter}

5.1 Prepare for the large scale demonstration to prove the effectiveness and economic viability of pneumatic injection. 


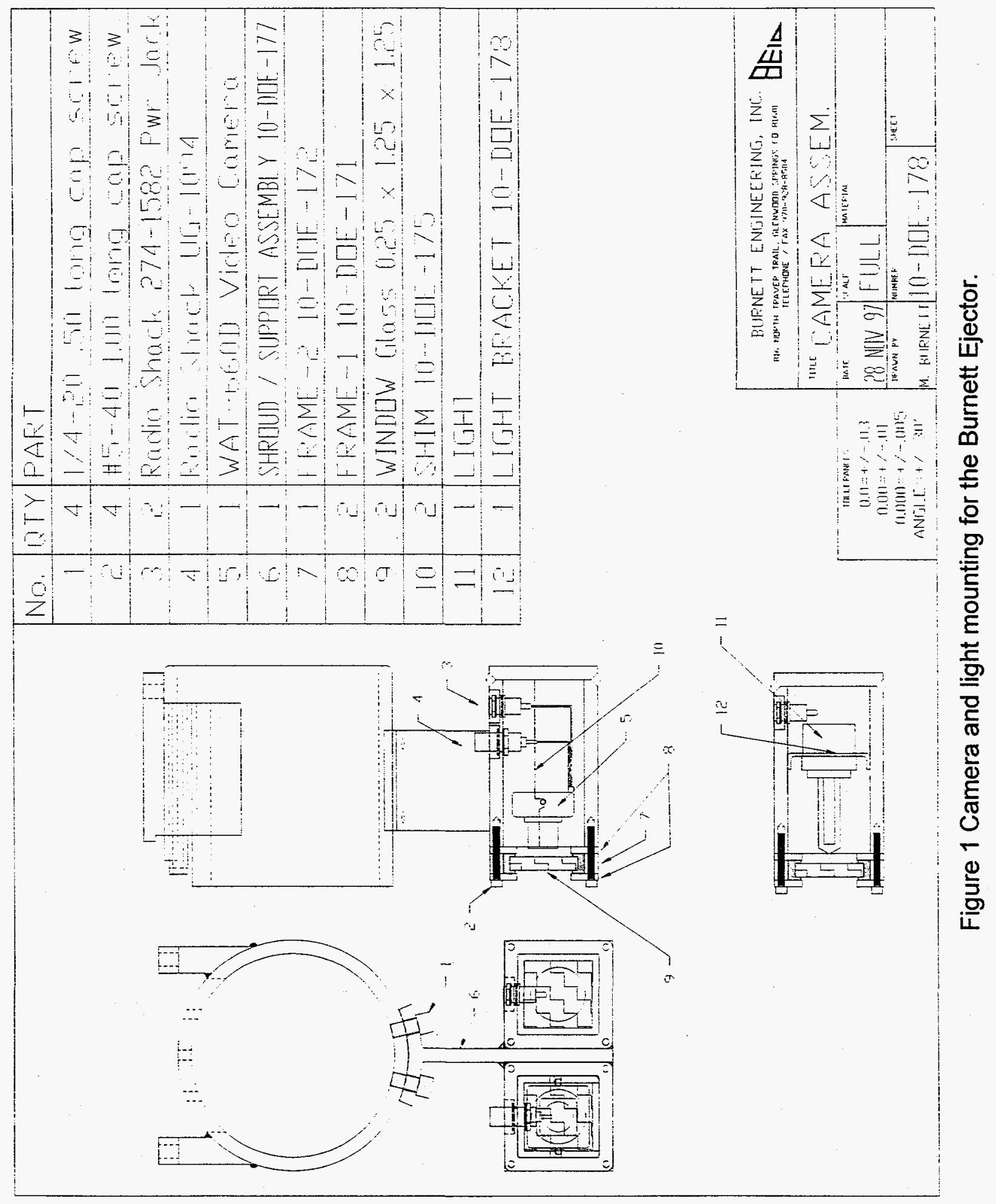




\section{Water Quality Monitoring}

\subsection{Task Description}

\section{Baseline Water Quality Monitoring}

The purpose of this task is to monitor the baseline water quality of the acid mine drainage (AMD) from the Longridge and Fairfax Mines prior to and during grouting. A flow monitoring and sampling station has been set up at the Longridge mine and a precipitation gauge has been established between the two mines.

\subsection{Summary of Period's Accomplishments \& Significant Events}

Water quality monitoring and sampling continued as planned. Data is presented and discussed in some detail below for the reporting period of approximately three months. Flow from the Longridge Mine averaged around 195 gallons per minute. Acidity concentrations ranged from $707 \mathrm{mg} / \mathrm{l}$ to $868 \mathrm{mg} / \mathrm{l}$.

Sampling from the well located below the Fairfax Mine coal seam was conducted. Data is presented below.

A power outage was discovered at the site August 29,1997 . This was due to a defective transformer and was repaired and the autosampler was place back online September 25, 1997.

\subsection{Accomplishments to Date}

Accomplishments to date include choice of parameters to sample, design of the sampling station, procurement of equipment, site preparation, installation and shake down of equipment, initiation of sampling and data analysis.

\subsection{Technical Progress Report}

Tables 1 and 2 display the water quality data collected from the Longridge mine. Metal concentrations were consistent for the period. Average daily flows ranged from 20 to 367 gallons per minute with an average of $195 \mathrm{gpm}$. Acidity concentrations were consistent as well ranging from 707 to $868 \mathrm{mg} / \mathrm{l}$ and averaging $792 \mathrm{mg} / \mathrm{l}$. The consistency of the concentrations can also be verified by noting the Conductivity and Sulfate levels.

Table 3 displays data from the Fairfax Groundwater Monitoring well. This well was established to check for contaminants leaching from the Phase II demonstration area. No water has been collected from the mine so the likelihood of leaching is very low. However, the well is a security measure and will continue to be monitored. Similar wells will be established at the Phase III Longridge Mine site. Upon review of the data, it can be concluded that no contaminants are leaching into the well. The water is alkaline and metal concentrations are below action limits.

All analyses were conducted by the National Research Center for Coal and Energy's Analytical Laboratory. The NRCCE Lab is certified by the State of 
West Virginia for all analytes reported.

\subsection{Plans for next Quarter}

5.1 Continue monitoring the Longridge mine for water quality and flow.

5.2 Continue to monitor Fairfax borehole for possible contamination from grout. 
TABLE 1

Patriot Mining

Longridge mine discharge Concentrations

\begin{tabular}{|c|c|c|c|c|c|c|c|c|c|c|c|c|c|c|c|c|c|c|c|c|c|}
\hline Date & Set & pH & Cond. & $\begin{array}{l}\text { Alkallinity } \\
\text { mg/l }\end{array}$ & $\begin{array}{l}\text { Acidity } \\
\text { mgh }\end{array}$ & $\begin{array}{c}\text { Al } \\
\text { mg/l }\end{array}$ & $\begin{array}{c}\text { As } \\
\mathrm{mg} / \mathrm{I}\end{array}$ & $\underset{m g n}{B}$ & $\begin{array}{c}\mathrm{Ba} \\
\mathrm{mg} / \mathrm{f}\end{array}$ & $\begin{array}{c}\mathrm{Ca} \\
\mathrm{mg} /\end{array}$ & $\begin{array}{c}\mathrm{Cd} \\
\mathrm{mg} /\end{array}$ & $\begin{array}{c}\mathrm{Fe} \\
\mathrm{mg} / \mathrm{I}\end{array}$ & $\underset{\mathrm{mg} / \mathrm{Mg}}{\mathrm{Mg}}$ & $\begin{array}{c}\mathrm{Mn} \\
\mathrm{mg} / 1\end{array}$ & $\begin{array}{c}\mathrm{Pb} \\
\mathrm{mg} / \mathrm{I}\end{array}$ & $\begin{array}{c}\text { Se } \\
\text { mg/l }\end{array}$ & $\begin{array}{l}\mathrm{sO4} \\
\mathrm{mg} / 1\end{array}$ & $\begin{array}{l}\text { Total Flow } \\
\text { gallions }\end{array}$ & $\begin{array}{l}\text { Min. Flow } \\
\text { gpm }\end{array}$ & $\begin{array}{l}\text { Max. Flow } \\
\text { gpm }\end{array}$ & $\begin{array}{l}\text { Ave. Flow } \\
\text { gpm }\end{array}$ \\
\hline $12-6-96$ & 100 & 2.72 & 2,020 & 0 & 597 & 43 & 0.380 & 0.070 & $<0.001$ & 76 & $<0.001$ & 84 & 47 & 14 & $<0.040$ & 0.330 & 970 & $2,501,192$ & 7.78 & 514.86 & 148.76 \\
\hline $12-13-96$ & 101 & 3.13 & 1,970 & 0 & 644 & 50 & 0.460 & $<0.030$ & $<0.001$ & 92 & $<0.001$ & 93 & 55 & 16 & $<0.040$ & 0.310 & 1100 & $2,287,667$ & 38.86 & 514.86 & 137.46 \\
\hline $12-27-96$ & 103 & 2.90 & 2,070 & 0 & 622 & 49 & 0.490 & 0,080 & 0.008 & 96 & $<0.001$ & 92 & 54 & 15 & 0.150 & 0.360 & 1200 & $1,107,530$ & 7.69 & 124.41 & 66.55 \\
\hline $1-4-97$ & 104 & 2.90 & 1,960 & 0 & 537 & 42 & 0.390 & 0.060 & 0.011 & 83 & $<0.001$ & 80 & 48 & 14 & 0.110 & 0.420 & 1000 & 713,899 & 72.21 & 137.76 & 101.18 \\
\hline $1-11-97$ & 105 & 2.98 & 2,050 & 0 & 585 & 47 & 0.500 & 0.078 & 0.012 & 93 & $<0.001$ & 90 & 52 & 14 & 0.110 & 0.440 & 1100 & 274,128 & 31.42 & 162.69 & 53.57 \\
\hline $1-21-97$ & 106 & 2.67 & 2,300 & 0 & 646 & 46 & 0.570 & 0.100 & 0.003 & 110 & $<0.001$ & 110 & 59 & 17 & 0.200 & 0.500 & 1100 & $\mathbf{8 0 5 . 8 1 9}$ & 10.32 & 162.69 & 48.42 \\
\hline $2-12-97$ & 108 & 2.65 & 2,000 & 0 & 644 & 41 & 0.500 & 0.092 & $<0.001$ & 120 & $<0.001$ & 110 & 78 & 18 & 0.150 & 0.460 & 1100 & $1,335,655$ & 29.93 & 140.82 & 66.24 \\
\hline $3-18-97$ & 109 & & & & & 58 & $<0.175$ & 0.210 & 0.045 & 109 & 0.012 & 102 & 59 & 19 & $<0.040$ & $<0.139$ & & $3,969,049$ & 47.04 & 482.14 & 165.42 \\
\hline 4-29-97 & 110 & 2.49 & 1,940 & 0 & 528 & 37 & 0.420 & 0.110 & $<0.001$ & 80 & $<0.001$ & 67 & 49 & 14 & 0.042 & 0.240 & 1100 & $2,850,658$ & 21.04 & 141.48 & 59.68 \\
\hline $5-29-97$ & 111 & 2.76 & 1.800 & 0 & 548 & 36 & 0.510 & 0.180 & 0.013 & 85 & 0.007 & 74 & 46 & 13 & 0.150 & 0.380 & 920 & $2,131,404$ & 21.04 & 178.98 & 60.37 \\
\hline $6-16-97$ & 112 & 2.73 & 1.920 & 0 & 633 & $40^{-}$ & 0.500 & $<0.030$ & 0.006 & 91 & 0.008 & 90 & 54 & 14 & 0.180 & 0.350 & 960 & $1,507,932$ & 3.78 & 104.9 & 38.48 \\
\hline $7-28-97$ & 113 & 2.68 & 1,740 & 0 & 533 & 46 & 0.480 & 0.150 & 0.003 & 100 & 0.010 & 98 & 59 & 14 & 0.160 & 0.450 & 1100 & 964,513 & 5.23 & 56.02 & 22.05 \\
\hline $8-29-97$ & 114 & 2.69 & 2,150 & 0 & 757 & 53 & 0.620 & 0.210 & 0.009 & 120 & 0.015 & 91 & 66 & 16 & 0.210 & 0.510 & 1000 & 259,863 & 8 & 30 & 16.41 \\
\hline $9-25-97$ & 115 & 2.73 & 2,280 & 0 & 868 & 73 & 0.800 & 0.210 & $<0.001$ & 160 & $<0.001$ & 150 & 86 & 23 & 0.260 & 0.630 & 1500 & 864,000 & estimated tot & al based on $\mathrm{gr}$ & rab sample of $20 \mathrm{gpm}$ \\
\hline $10-17-97$ & 116 & 2.76 & 2,110 & 0 & 800 & 67 & 0.710 & 0.190 & 0.013 & 160 & 0.015 & 140 & 82 & 23 & 0.220 & 0.620 & 1800 & $6,560,863$ & 265 & 546 & 198 \\
\hline $11-19-97$ & 117 & 2.84 & 1,880 & 0 & 707 & 58 & 0.500 & 0.140 & $<0.1$ & 120 & $<0.1$ & 130 & 80 & 24 & 0.170 & 0.410 & 1600 & $17,494,164$ & 115 & 516 & 367 \\
\hline
\end{tabular}




\section{TABLE 2 Patriot Mining}

Longridge mine discharge Loadings

\begin{tabular}{|c|c|c|c|c|c|c|c|c|c|c|c|c|c|c|c|}
\hline Date & Set & $\begin{array}{l}\text { Alkalinity } \\
\text { Pounds }\end{array}$ & $\begin{array}{l}\text { Acidity } \\
\text { Pounds }\end{array}$ & $\begin{array}{c}\text { Al } \\
\text { Pounds }\end{array}$ & $\begin{array}{c}\text { As } \\
\text { Pounds }\end{array}$ & $\begin{array}{c}\text { B } \\
\text { Pounds }\end{array}$ & $\begin{array}{c}\text { Ba } \\
\text { Pounds }\end{array}$ & $\begin{array}{c}\text { Ca } \\
\text { Pounds }\end{array}$ & $\begin{array}{c}\text { Cd } \\
\text { Pounds }\end{array}$ & $\begin{array}{c}\text { Fe } \\
\text { Pounds }\end{array}$ & $\begin{array}{c}\text { Mg } \\
\text { Pounds }\end{array}$ & $\begin{array}{c}\text { Mn } \\
\text { Pounds }\end{array}$ & $\begin{array}{c}\text { Pb } \\
\text { Pounds }\end{array}$ & $\begin{array}{c}\text { Se } \\
\text { Pounds }\end{array}$ & $\begin{array}{c}\text { SO4 } \\
\text { Pounds }\end{array}$ \\
\hline $12-6-96$ & 100 & 0 & 12,434 & 896 & 7.91 & 1.46 & 0.00 & 1,583 & 0.00 & 1,750 & 979 & 292 & 0.00 & 6.87 & 20,203 \\
\hline $12-13-96$ & 101 & 0 & 12,268 & 952 & 8.76 & 0.00 & 0.00 & 1,753 & 0.00 & 1,772 & 1,048 & 305 & 0.00 & 5.91 & 20,954 \\
\hline $12-27-96$ & 103 & 0 & 5,736 & 452 & 4.52 & 0.74 & 0.07 & 885 & 0.00 & 848 & 498 & 138 & 1.38 & 3.32 & 11,067 \\
\hline $1-4-97$ & 104 & 0 & 3,192 & 250 & 2.32 & 0.36 & 0.07 & 493 & 0.00 & 476 & 285 & 83 & 0.65 & 2.50 & 5,945 \\
\hline $1-11-97$ & 105 & 0 & 1,335 & 107 & 1.14 & 0.18 & 0.03 & 212 & 0.00 & 205 & 119 & 32 & 0.25 & 1.00 & 2,511 \\
\hline $1-21-97$ & 106 & 0 & 4,335 & 309 & 3.82 & 0.67 & 0.02 & 738 & 0.00 & 738 & 396 & 114 & 1.34 & 3.36 & 7,381 \\
\hline $2-12-97$ & 108 & 0 & 7,163 & 456 & 5.56 & 1.02 & 0.00 & 1,335 & 0.00 & 1,223 & 868 & 200 & 1.67 & 5.12 & 12,234 \\
\hline $3-18-97$ & 109 & 0 & 0 & 1,917 & 0.00 & 6.94 & 1.49 & 3,602 & 0.40 & 3,371 & 1,950 & 628 & 0.00 & 0.00 & 0 \\
\hline $4-29-97$ & 110 & 0 & 12,533 & 878 & 9.97 & 2.61 & 0.00 & 1,899 & 0.00 & 1,590 & 1,163 & 332 & 1.00 & 5.70 & 26,111 \\
\hline $5-29-97$ & 111 & 0 & 9,726 & 639 & 9.05 & 3.19 & 0.23 & 1,509 & 0.13 & 1,313 & 816 & 231 & 2.66 & 6.74 & 16,328 \\
\hline $6-16-97$ & 112 & 0 & 7,948 & 502 & 6.28 & 0.00 & 0.08 & 1,143 & 0.10 & 1,130 & 678 & 176 & 2.26 & 4.39 & 12,054 \\
\hline $7-28-97$ & 113 & 0 & 4,281 & 369 & 3.86 & 1.20 & 0.02 & 803 & 0.08 & 787 & 474 & 112 & 1.29 & 3.61 & 8,835 \\
\hline $8-29-97$ & 114 & 0 & 1,638 & 115 & 1.34 & 0.45 & 0.02 & 260 & 0.03 & 197 & 143 & 35 & 0.45 & 1.10 & 2,164 \\
\hline $9-25-97$ & 115 & 0 & 6,245 & 525 & 5.76 & 1.51 & 0.00 & 1,151 & 0.00 & 1,079 & 619 & 165 & 1.87 & 4.53 & 10,792 \\
\hline $10-17-97$ & 116 & 0 & 43,706 & 3,660 & 38.79 & 10.38 & 0.71 & 8,741 & 0.82 & 7,649 & 4,480 & 1257 & 12.02 & 33.87 & 98,338 \\
\hline $11-19-97$ & 117 & 0 & 102,991 & 8,449 & 72.84 & 20.39 & 0.00 & 17,481 & 0.00 & 18,938 & 11,654 & 3496 & 24.76 & 59.73 & 233,078 \\
\hline
\end{tabular}




\section{TABLE $3 \quad$ Patriot Mining}

Fairfax groundwater monitoring well

\begin{tabular}{|c|c|c|c|c|c|c|c|c|c|c|c|c|c|c|c|c|c|}
\hline $\begin{array}{l}1-11-97 \\
2-12-97\end{array}$ & $\begin{array}{l}105 F \\
108 F\end{array}$ & $\begin{array}{l}7.51 \\
7.37\end{array}$ & $\begin{array}{l}540 \\
430\end{array}$ & $\begin{array}{c}\text { Alkalinity } \\
\text { mg/l } \\
140 \\
139\end{array}$ & $\begin{array}{c}\text { Acidity } \\
\text { mg/l } \\
0 \\
0\end{array}$ & $\begin{array}{c}\mathrm{Al} \\
\mathrm{mg} / 1 \\
1.6 \\
1.2\end{array}$ & $\begin{array}{c}\text { As } \\
\mathrm{mg} / 1 \\
<0.175 \\
<0.175\end{array}$ & $\begin{array}{c}\mathbf{B} \\
\mathrm{mg} / 1 \\
<0.030 \\
<0.030\end{array}$ & $\begin{array}{l}\mathrm{Ba} \\
\mathrm{mg} / \mathrm{l} \\
0.15 \\
0.10\end{array}$ & $\begin{array}{c}\mathrm{Ca} \\
\mathrm{mg} / 1 \\
44 \\
40 \\
\end{array}$ & $\begin{array}{c}\mathrm{Cd} \\
\mathrm{mg} / 1 \\
<0.001 \\
<0.001 \\
\end{array}$ & $\begin{array}{c}\mathbf{F e} \\
\mathrm{mg} / 1 \\
0.33 \\
0.42 \\
\end{array}$ & $\begin{array}{c}\mathrm{Mg} \\
\mathrm{mg} / 1 \\
10 \\
8.4 \\
\end{array}$ & $\begin{array}{c}\mathrm{Mn} \\
\mathrm{mg} / 1 \\
0.086 \\
0.084\end{array}$ & $\begin{array}{c}\mathbf{P b} \\
\mathrm{mg} / 1 \\
<0.040 \\
<0.040 \\
\end{array}$ & $\begin{array}{c}\mathrm{Se} \\
\mathrm{mg} / \mathrm{l} \\
<0.139 \\
<0.139 \\
\end{array}$ & $\begin{array}{c}\mathrm{SO} 4 \\
\mathrm{mg} / \mathrm{l} \\
120 \\
96 \\
\end{array}$ \\
\hline $3-18-97$ & $109 \mathrm{~F}$ & & & & & 0.176 & $<0.175$ & $<0.030$ & 0.27 & 40 & 0.001 & 0.11 & 8.9 & 0.045 & $<0.040$ & $<0.139$ & \\
\hline $4-30-97$ & $110 \mathrm{~F}$ & 7.35 & 403 & 141 & 0 & 0.94 & $<0.175$ & 0.11 & 0.13 & 31 & $<0.001$ & 0.37 & 7.8 & 0.048 & $<0.040$ & $<0.139$ & 96 \\
\hline $5-29-97$ & $111 \mathrm{~F}$ & 7.37 & 335 & 190 & 0 & 0.86 & $<0.175$ & 0.11 & 0.14 & 27 & $<0.001$ & 0.18 & 6.1 & 0.021 & $<0.040$ & $<0.139$ & 76 \\
\hline $6-16-97$ & $112 \mathrm{~F}$ & 6.81 & 350 & 122 & 0 & 1.2 & $<0.175$ & 0.2 & 0.14 & 28 & $<0.001$ & 1.1 & 6.5 & 0.19 & $<0.040$ & $<0.139$ & 59 \\
\hline $7-28-97$ & $113 F$ & 7.76 & 340 & 134 & 0 & 0.73 & $<0.175$ & 0.12 & 0.12 & 21 & $<0.001$ & 0.17 & 4.7 & 0.025 & $<0.040$ & $<0.139$ & 35 \\
\hline $8-29-97$ & $114 \mathrm{~F}$ & 7.29 & 300 & 118 & 0 & 0.82 & $<0.175$ & 0.1 & 0.14 & 22 & $<0.001$ & 0.28 & 4.6 & 0.052 & $<0.040$ & $<0.139$ & 69 \\
\hline $9-25-97$ & $115 \mathrm{~F}$ & 7.55 & 370 & 138 & 0 & 0.72 & $<0.175$ & $<0.030$ & 0.16 & 20 & $<0.001$ & 0.24 & 4.5 & $<0.002$ & $<0.040$ & $<0.139$ & 34 \\
\hline $10-17-97$ & $116 \mathrm{~F}$ & 7.70 & 440 & 133 & 0 & 0.7 & $<0.175$ & 0.054 & 0.17 & 19 & 0.0062 & 0.22 & 4.3 & 0.044 & $<0.040$ & $<0.139$ & 44 \\
\hline $11-19-97$ & $117 \mathrm{~F}$ & 7.30 & 280 & 132 & 0 & 0.69 & $<0.175$ & $<0.1$ & 0.17 & 19 & $<0.1$ & 0.12 & 4.1 & $<0.1$ & $<0.1$ & $<0.1$ & 40 \\
\hline
\end{tabular}




\section{Contaminant Transport}

\subsection{Task Description}

\section{Task 6.0 Contaminant Transport}

Determine how contaminants will migrate from the grout (if any) and determine how the water that was filling the void will interact with the impermeable plug filling the void after injection.

\subsection{Summary of Quarters Accomplishments and Significant Events}

2.1 Modeling of Contaminant Transport at the Longridge mine was continued to study the influence of grouting.

\subsection{To Date Accomplishments}

3.1 The Longridge Mine was idealized for the task on modeling the contaminant transport.

3.2 A finite element difference grid for the idealized Longridge mine was constructed and some example groundwater flow problems were solved using the existing computer software.

\subsection{Technical Progress Report}

A detailed topical report on this task is being prepared. It will be forwarded to U.S. Department of Energy as soon as it is ready for release.

\subsection{Plans for the Next Quarter}

5.1 A detailed report on this task will be prepared. 